University of Nebraska - Lincoln

DigitalCommons@University of Nebraska - Lincoln

Faculty Publications, Department of Psychology

Psychology, Department of

2008

Predictors of Goggle Use among Racquetball Players

Carmen P. McLean

Boston Veterans' Administration, carmen.mclean@va.gov

David K. DiLillo

University of Nebraska-Lincoln, ddilillo@unl.edu

Brian H. Bornstein

University of Nebraska-Lincoln, bbornstein2@unl.edu

R. V. Bevini

University of Nebraska-Lincoln

Follow this and additional works at: https://digitalcommons.unl.edu/psychfacpub

Part of the Psychiatry and Psychology Commons

McLean, Carmen P.; DiLillo, David K.; Bornstein, Brian H.; and Bevini, R. V., "Predictors of Goggle Use among Racquetball Players" (2008). Faculty Publications, Department of Psychology. 581.

https://digitalcommons.unl.edu/psychfacpub/581

This Article is brought to you for free and open access by the Psychology, Department of at DigitalCommons@University of Nebraska - Lincoln. It has been accepted for inclusion in Faculty Publications, Department of Psychology by an authorized administrator of DigitalCommons@University of Nebraska - Lincoln. 


\title{
Predictors of goggle use among racquetball players
}

\author{
C.P. McLean*, D. DiLillo, B.H. Bornstein and R.A. Bevini \\ The University of Nebraska - Lincoln, Nebraska, USA \\ (Received 11 January 2008; final version received 15 April 2008)
}

\section{Introduction}

Racquetball is a popular, high-intensity competitive sport that requires quick reflexes and keen spatial awareness. Players may be vulnerable to eye injuries, which could be prevented through use of proper protective eyewear (Feigelman, Sugar, Jednock, Read, \& Johnson, 1983). Given the low rates of goggle use among squash players (Eime, Owen, \& Finch, 2004), the use of goggles among racquetball players is suspected to be low. However, to date there have been no studies investigating predictors of goggle use in racquetball players. Understanding the rates and predictors of goggle use among racquetball players is an important prerequisite to developing effective intervention programmes. The present study explores: (a) the rate of goggle use in a sample of racquetball players from the Midwest US; (b) self-reported reasons for use/non-use, and; (c) the relationship between demographic variables, player characteristics, and behavioural variables and cognitive variables.

\section{Methods}

Participants were racquetball players (202 men and 62 women) recruited from the campus recreation centre at a large Midwest university in the US ( $\mathrm{M}$ age $=24.66$ years, $\mathrm{SD}=9.52)$. Participants were primarily students $(83.11 \%)$; the majority $(88.45 \%)$ were Caucasian.

\subsection{Racquetball questionnaire}

A questionnaire was designed to measure the basic demographic information, player characteristics (e.g. number of years playing racquetball, how often goggles are worn during play), and reasons for use (e.g. 'I experienced an eye injury before') and non-use of goggles (e.g. 'Goggles are uncomfortable to wear').

\subsection{Procedure}

Participants were recruited by research assistants immediately before or after playing racquetball, or during a break in play. Following informed consent, participants completed the racquetball questionnaire. The response rate was $93.5 \%$. The 18 individuals who declined participation cited time constraints as their reason for refusal.

\subsection{Preliminary analyses}

Between-group comparisons were based on analysis of variance (ANOVA) for continuous variables and chisquare tests for categorical variables. Assumptions of normality and homogeneity of variances were met. Preliminary analyses revealed significant gender differences in player characteristics. Thus, subsequent analyses were conducted separately by gender. For all analyses, current participation in a college course in racquetball was entered as a covariate in order to control the influence of the class requirement to use goggles during the class period.

\section{Results}

\subsection{Player characteristics}

Player characteristics of men and women are shown in Table 1 . The majority of men and women reported that they never wore goggles, and only a minority reported that they always wore goggles. Men were significantly more likely than women to own goggles, and reported having played racquetball for more years, playing

\footnotetext{
*Corresponding author. Email: carmen.mclean@va.gov

ISSN 1745-7300 print/ISSN 1745-7319 online 
Table 1. Comparison of player characteristics in male and female racquetball players.

\begin{tabular}{|c|c|c|c|}
\hline $\begin{array}{l}\text { Player } \\
\text { characteristic }\end{array}$ & $\begin{array}{c}\text { Men } \\
(\mathrm{SD}) \\
n=202\end{array}$ & $\begin{array}{c}\text { Women } \\
\text { (SD) } \\
n=62\end{array}$ & $\begin{array}{l}\text { Test-statistics } \\
\text { and } p \text {-value } \\
\text { for gender } \\
\text { comparison }\end{array}$ \\
\hline $\begin{array}{l}\text { Years playing } \\
\text { racquetball }\end{array}$ & $\begin{array}{c}4.84 \\
(7.48)\end{array}$ & $\begin{array}{l}2.21 \\
(0.62)\end{array}$ & $\mathrm{F}_{(1262)}=6.85^{* *}$ \\
\hline Frequency of play & & & $X^{2}=22.40 * * *$ \\
\hline $\begin{array}{l}\text { Less than } \\
\text { once a } \\
\text { year }(\%)\end{array}$ & 7.52 & 22.63 & \\
\hline $\begin{array}{l}\text { A few times } \\
\text { a year }(\%)\end{array}$ & 8.00 & 19.44 & \\
\hline $\begin{array}{l}1-2 \text { times per } \\
\text { month }(\%)\end{array}$ & 25.43 & 9.70 & \\
\hline $\begin{array}{l}\text { Once per } \\
\text { week }(\%)\end{array}$ & $29.44 \%$ & 27.41 & \\
\hline $\begin{array}{l}\text { Several times } \\
\text { a week }(\%)\end{array}$ & 29.95 & 21.00 & \\
\hline Perceived skill & & & $X^{2}=27.00^{* * *}$ \\
\hline $\begin{array}{l}\text { Very unskilled } \\
(\%)\end{array}$ & 8.51 & 31.12 & \\
\hline $\begin{array}{l}\text { Somewhat } \\
\quad \text { unskilled }(\%)\end{array}$ & 18.92 & 21.34 & \\
\hline $\begin{array}{l}\text { Average } \\
\quad \text { skill }(\%)\end{array}$ & 48.81 & 42.60 & \\
\hline $\begin{array}{l}\text { Somewhat } \\
\text { skilled }(\%)\end{array}$ & 18.43 & 4.91 & \\
\hline $\begin{array}{l}\text { Very skilled } \\
(\%)\end{array}$ & 5.54 & 0.00 & \\
\hline $\begin{array}{l}\text { Owns goggles } \\
(\%)\end{array}$ & 37.12 & 22.62 & $F_{(1262)}=4.54^{*}$ \\
\hline $\begin{array}{l}\text { Enrolled in } \\
\text { a course } \\
\text { requiring } \\
\text { goggles }\end{array}$ & 4.51 & 12.94 & $\mathrm{~F}_{(1261)}=5.64 *$ \\
\hline $\begin{array}{c}\text { Frequency of } \\
\text { goggle use }\end{array}$ & & & $\mathrm{F}_{(1262)}=7.34^{\mathrm{a} * *}$ \\
\hline Never (\%) & 58.43 & 77.42 & \\
\hline $\begin{array}{l}\text { Sometimes } \\
(\%)\end{array}$ & 10.43 & 1.65 & \\
\hline $\begin{array}{l}\text { About half } \\
\text { the time }(\%)\end{array}$ & 3.50 & 4.84 & \\
\hline Often $(\%)$ & 4.00 & 1.61 & \\
\hline Always (\%) & 23.81 & 14.55 & \\
\hline $\begin{array}{l}\text { Knows recreation } \\
\text { centre loans } \\
\text { goggles }(\%)\end{array}$ & 34.82 & 24.35 & $\mathrm{~F}_{(1258)}=2.46$ \\
\hline $\begin{array}{l}\text { Number of past } \\
\text { sports } \\
\text { injuries }(\%)\end{array}$ & $\begin{array}{l}2.18 \\
(2.55)\end{array}$ & $\begin{array}{c}0.98 \\
(1.67)\end{array}$ & $\mathrm{F}_{(1250)}=11.71 * * *$ \\
\hline
\end{tabular}

${ }^{\mathrm{a}}$ Frequency of goggle use was recalculated as a binary variable: never wear goggles or wear goggles at least sometimes.

$* p<0.05$.

$* * p<0.01$.

$*_{* *} p<0.001$.

more frequently and rated themselves as more skilled. Although the frequency of goggle use was greater among men than women, this difference was not significant after controlling for skill-related player characteristics and past sports injuries.

\subsection{Reasons for use and non-use of goggles}

Table 2 shows the reasons for which the participants were endorsed for wearing or not wearing goggles. Among participants who never wore goggles, the most frequent reason was 'I never really thought about wearing goggles'. Women were more likely than men to endorse skill-related reasons for nonuse, whereas men endorsed reasons for use related to past injury. A minority of the sample reported wearing goggles at least sometimes, and most frequently reported their reason for use as 'to prevent eye injury'.

\subsection{Predictors of goggle use}

Frequency of play and number of years playing racquetball significantly predicted goggle use among men. Goggle use was greater among men who were older, were faculty or staff rather than students, perceived themselves as more skilled, owned goggles, and knew that the recreation centre loaned goggles for free. Only greater frequency of play and owning goggles significantly predicted goggle use among women.

\section{Discussion}

The most commonly reported reason for never using goggles was 'I never really thought about wearing goggles.' Women, but not men, were more likely to believe that inexperience and low-intensity play negated the need to wear goggles. The notion that injury is less likely among low-intensity or beginning players lacks support (Soderstrom \& Doxanas, 1982). Thus, women who are beginners or perceive themselves as less skilled may have an elevated risk for eye injury.

\subsection{Reasons for use and non-use of goggles}

A minority of participants who never wore goggles endorsed equipment-related reasons such as cost, discomfort, or restricted vision for non-use. It is unclear whether these individuals have tried recent models of goggles; Eime, McCarty, Finch, and Owen (2005) found that most squash players reporting such concerns had never used goggles.

\subsection{Predictors of goggle use}

The predictors of goggle use in this study differed across genders. However, these gender differences were accounted for by certain player characteristics. Compared with women, men perceived themselves as more 
Table 2. Comparison of the proportion of male and female racquetball players endorsing reasons for wearing or not wearing goggles.

\begin{tabular}{|c|c|c|c|}
\hline & $\begin{array}{c}\text { Men } \\
(n=118)\end{array}$ & $\begin{array}{l}\text { Women } \\
(n=48)\end{array}$ & $\begin{array}{l}\text { Test-statistics and } p \text {-value } \\
\text { for gender comparison }\end{array}$ \\
\hline $\begin{array}{l}\text { Reason for not wearing among those who never wear goge } \\
\text { I never really thought about wearing goggles }(\%) \\
\text { I'm a beginner }(\%) \\
\text { The intensity of play is low }(\%) \\
\text { Goggles are uncomfortable }(\%) \\
\text { I don't like the way goggles look on me }(\%) \\
\text { The chances of getting injured are low }(\%) \\
\text { Goggles aren't masculine/feminine }(\%) \\
\text { Goggles restrict my vision }(\%) \\
\text { Sometimes I forget to bring goggles }(\%) \\
\text { I wear regular glasses instead of goggles }(\%) \\
\text { I don't want to spend money }(\%)\end{array}$ & $\begin{array}{r}44.97 \\
26.32 \\
23.73 \\
42.42 \\
13.64 \\
39.00 \\
4.22 \\
33.16 \\
1.75 \\
10.22 \\
44.15 \\
n=84\end{array}$ & $\begin{array}{r}47.93 \\
58.35 \\
50.00 \\
35.43 \\
20.81 \\
29.23 \\
0.00 \\
25.00 \\
4.20 \\
10.43 \\
39.64 \\
n=14\end{array}$ & $\begin{array}{l}X^{2}=2.71 \\
X^{2}=25.72^{* * *} \\
X^{2}=12.08^{* * *} \\
X^{2}=0.34 \\
X^{2}=1.83 \\
X^{2}=0.25 \\
X^{2}=1.88 \\
X^{2}=1.00 \\
X^{2}=0.33 \\
X^{2}=0.04 \\
X^{2}=0.48\end{array}$ \\
\hline $\begin{array}{l}\text { Reason for wearing goggles among those who wear goggle } \\
\text { To prevent eye injury (\%) } \\
\text { I experienced an eye injury before }(\%) \\
\text { I know of someone who got injured }(\%) \\
\text { I wear prescription goggles that help me see better }(\%) \\
\text { Someone recommended that I wear goggles }(\%) \\
\text { I started using goggles as a result of taking a } \\
\text { racquetball class that required goggles }(\%)\end{array}$ & $\begin{array}{l}\text { st sometim } \\
89.33 \\
14.32 \\
22.61 \\
7.12 \\
34.54 \\
9.53\end{array}$ & $\begin{array}{c}100 \\
0.00 \\
7.12 \\
0.00 \\
50.00 \\
35.74\end{array}$ & $\begin{array}{l}X^{2}=5.32^{*} \\
X^{2}=3.89^{b} \\
X^{2}=4.79^{*} \\
X^{2}=1.88^{b} \\
X^{2}=0.32 \\
X^{2}=1.71\end{array}$ \\
\hline
\end{tabular}

skilled, had more experience playing, played more frequently, and were more likely to have experienced a past eye injury. After controlling for these differences, no gender differences in goggle use were observed.

\subsection{Limitations}

University students and employees were overrepresented in this sample, and participants' responses were not corroborated by observation. Furthermore, the present study did not specify the type of goggles, leaving the participants to determine the definition of safety goggles.

\section{Conclusion}

The majority of racquetball players in this study reported not using goggles and that they had never given much thought to doing so. Players who perceived their risk of injury to be low and the cost and comfort of goggles to be unacceptable were least likely to report using goggles. This suggests the need for increased awareness of injury risk and free access to comfortable, effective eyewear as a first step towards promoting goggle use. However, education rarely leads to significant behaviour change in the absence of a broader ecological approach (Eime et al., 2004).

The present findings are consistent with Eime et al.'s (2004) Protective Eyewear Promotion (PEP) model. This model suggests that educating squash players regarding the need for appropriate eyewear, increasing the availability of eyewear, making specific recommendations for use, and offering incentives for eyewear adoption all help to promote behaviour change. A recent effectiveness study indicated that PEP was associated with increased use of goggles by squash players (Eime, Finch, Wolfe, \& McCarty, 2005). Similar intervention studies among racquetball players are needed and would help inform efforts to reduce the incidence of racquetball-related eye injury.

\section{References}

Eime, R., Finch, C.F., Wolfe, R., \& McCarty, C. (2005). The effectiveness of a squash eyewear promotion strategy. British Journal of Sports Medicine, 39, 681-685.

Eime, R., McCarty, C., Finch, C.F., \& Owen, N. (2005). Unprotected eyes in squash: Not seeing the risk of injury. Journal of Science and Medicine in Sport, 8, 92-100. 
Eime, R., Owen, N., \& Finch, C. (2004). Protective Eyewear Promotion: Applying Principles of behaviour change in the design of a squash injury prevention programme. Sports Medicine, 34, 629-638.

Feigelman, M.J., Sugar, J., Jednock, N., Read, J.S., \& Johnson, P.L. (1983). Assessment of ocular protection for racquetball. Journal of the American Medical Association, 250, 3305-3309.
Soderstrom, C.A., \& Doxanas, M.T. (1982). Racquetball. A game with preventable injuries. American Journal of Sports Medicine, 10, 180-183. 
Copyright of International Journal of Injury Control \& Safety Promotion is the property of Taylor \& Francis Ltd and its content may not be copied or emailed to multiple sites or posted to a listserv without the copyright holder's express written permission. However, users may print. download, or email articles for individual use. 